\title{
A Simple and Rapid Method for the Determination of Nicotine in Third-Hand Smoke by Liquid Chromatography and Its Application for the Assessment of Contaminated Outdoor Communal Areas
}

\author{
Samira Inácia Santos e Silva ${ }^{a}$, Paul Bowdler ${ }^{b}$, Danielle Giltrow ${ }^{b}$, \\ Stephanie Riddell $^{b}$ and Kevin C. Honeychurch ${ }^{b^{*}}$ \\ ${ }^{a}$ Present address: Universidade Federal de Minas Gerais (UFMG) - Avenida Presidente Antônio \\ Carlos, 6627, Pampulha, Belo Horizonte - MG, 31270-901, Brazil \\ ${ }^{b}$ Centre for Research in Biosciences, Faculty of Health \& Life Sciences, University of the West of \\ England, Frenchay Campus, Coldharbour Lane, Bristol, BS16 1QY, UK, "kevin.honeychurch@uwe.ac.uk
}

\section{Abstract}

This is the first report on the determination of nicotine in third-hand smoke (THS) in outdoor communal areas. THS can be defined as the contamination of surfaces by second-hand smoke. This can remain for periods of time and undergo further chemical reactions to produce further pollutants which can be re-suspended in dust or re-emitted into the gas phase. As THS is a rather complex mixture studies have focused on using nicotine as a marker of THS, as it is the most abundant organic compound emitted during smoking. In this present study, the extraction of dust wipe samples and the subsequent chromatographic conditions required for the separation of nicotine by hydrophilic interaction liquid chromatography were optimised. The optimum chromatographic conditions were identified as a $150 \mathrm{~mm} \times 4.6 \mathrm{~mm}, 5 \mu \mathrm{m}$ Zorbax Carbohydrate Analysis column with a mobile phase consisting of $90 \%$ acetonitrile, $10 \%$ water at a flow rate of $1.0 \mathrm{~mL} / \mathrm{min}$ with UV detection at $259 \mathrm{~nm}$. Further investigations were made on samples collected from surfaces of public entrance ways. Under these conditions, a linear range for nicotine of 0.05 to $24 \mu \mathrm{g} / \mathrm{mL}(1.0 \mathrm{ng}-480$ $\mathrm{ng}$ on column) was obtained, with a detection limit of $1.0 \mathrm{ng}$ on column based on a signal-to-noise 
ratio of three. Acetone, naphthalene, phenol, musk ketone and palmitic acid were found not to interfere. Entrances were found to be contaminated with THS nicotine between $5.09 \mu \mathrm{g} / \mathrm{m}^{2}$ and 309 $\mu \mathrm{g} / \mathrm{m}^{2}$ notably higher than that found in studies of indoor environments.

Keywords: Third-hand smoke; HILIC; dust wipe; nicotine; communal areas; outdoor

\section{Introduction}

The terms first and second-hand smoke have been used for some time and commonly first-hand smoke is defined as what is inhaled into the lungs of the smoker, while second-hand smoke is a mixture of exhaled smoke and other substances leaving the smouldering end of the cigarette that enters the atmosphere and can be inhaled by others. The term third-hand smoke (THS) is relatively new [1-3], defined as the contamination that remains on the surfaces after smoking source has been removed $[4,5]$. Nicotine present in the tobacco smoke residue can combine with other compounds such as ozone and nitrous oxide to produce recognized carcinogens such as nitrosamines [6-11]. Studies by Martins-Green et al [6] have shown that mice exposed to THS exhibit poor healing processes, produce excess collagen and high levels of inflammatory cytokines, conditions which can lead to inflammation-induced diseases such as chronic obstructive pulmonary disease and asthma. Behavioural tests undertaken in the same investigation showed THS-exposed mice also exhibited increased hyperactivity [6]. The effects of THS are predicted to be more severe for children as they are still developing and also ingest more dust particles as they explore objects with their mouths [12$15]$.

In the UK, smoking has been banned in enclosed buildings and indoor areas since the $1^{\text {st }}$ July 2007 as a consequence of the Health Act 2006. This has resulted in people generally congregating in areas close to building entrances in order to smoke. This can result in both issues with second-hand smoke and third-hand exposure to themselves and unrelated people in the vicinity and when using entrance ways.

As THS is a rather complex mixture, studies have focused on using nicotine as a marker as it is the most abundant organic compound emitted during smoking [16] and a number of different methods 
have been reported for its determination [17], such as ion mobility spectroscopy [18] and voltammetry [19]. Previous studies of THS have utilised sophisticated and expensive analytical equipment such as tandem mass spectroscopy and two-dimensional gas chromatography (table 1).

The analysis of some amines such as nicotine by reverse phase HPLC can lead to problems due to their hydrophilic nature leading to low retention; necessitating the use of ion pairing agents [20], buffers, or low concentrations of organic modifier [21] which can cause stationary phase de-wetting. The presence of ionised silanol groups on the stationary phase can also result in peak tailing and overloading leading to poor separation and analytical performance [22,23]. Hydrophilic interaction liquid chromatography (HILIC) is becoming an established alternative technique to overcome these issues $[24,25]$. The high percentages of acetonitrile generally used with HILIC result in mobile phases with low viscosities allowing for greater flow rates ranges to be utilised resulting in increased analytical throughput and low backpressures which can lead to improved signal-to-noise ratios.

In this present study we have used the collection of dust wipe samples to investigate the extent of THS within our university campus to assess exposure to individuals. Dust wipe samples were analysed by HILIC with UV detection to identify and quantify nicotine present. This represents a simpler and cheaper alternative method using instrumentation normally found in most laboratories. 


\begin{tabular}{|c|c|c|c|}
\hline Analytical Technique & Nicotine Levels Third-Hand Smoke $\left(\mu \mathrm{g} / \mathrm{m}^{2}\right)$ & Comments & Ref. \\
\hline $\begin{array}{l}\text { Liquid } \\
\text { chromatography- } \\
\text { tandem mass } \\
\text { spectrometry }\end{array}$ & $\begin{array}{l}\text { Hotels with complete smoking ban guestrooms, mean } 1.4 \text {, } \\
\text { hallways, } 1.2 \text {. } \\
\text { Hotels without complete smoking ban; non-smoking } \\
\text { guestrooms, mean 3.7; smoking guestrooms, } 51.8 \text {. Hallways } \\
\text { outside non-smoking rooms, 2.8; hallways outside smoking } \\
\text { rooms, 9.3. }\end{array}$ & $\begin{array}{l}\text { Air concentrations of nicotine also investigated. Air and } \\
\text { surface concentrations of 3-ethynylpyridine } \\
\text { concentrations also investigated. }\end{array}$ & {$[26]$} \\
\hline $\begin{array}{l}\text { Liquid } \\
\text { chromatography- } \\
\text { tandem mass } \\
\text { spectrometry }\end{array}$ & $\begin{array}{l}\text { Non-smoking environment } 1.8-5.3 \text {. Smoking environments } \\
57.2-113.5 \text {. }\end{array}$ & $\begin{array}{l}\text { Wipe sampling for nicotine in private homes, private cars, } \\
\text { rental cars, and hotels with and without smoking bans. }\end{array}$ & [10] \\
\hline $\begin{array}{l}\text { Liquid chromatography } \\
\text { tandem mass } \\
\text { spectrometry }\end{array}$ & $\begin{array}{l}\text { Geometric mean surface nicotine concentrations of non- } \\
\text { smoking and smoking homes } 11.4,90.9 \text { respectively between } \\
\text { homes with complete, partial and no voluntary home smoking } \\
\text { restrictions } 8.9,56.3 \text { vs. } 145.6 \text { respectively. }\end{array}$ & & [27] \\
\hline $\begin{array}{l}\text { Liquid } \\
\text { chromatography- } \\
\text { tandem mass } \\
\text { spectrometry }\end{array}$ & $\begin{array}{l}\text { Living rooms; geometric mean, 83.67. Child bedrooms: } \\
\text { geometric mean, } 64.6 \text {. }\end{array}$ & $\begin{array}{l}\text { Analysis of the homes of Hookah smokers. Indoor air } \\
\text { nicotine, 4-(methylnitrosamino)-1-(3-pyridyl)-1-butanone } \\
\text { (NNK), acrolein, cotinine, 4-(methylnitrosamino)-1-(3- } \\
\text { pyridyl)-1-butanol (NNAL) and NNAL-glucuronides (total } \\
\text { NNAL) and 3-hydroxypropylmercapturic acid also } \\
\text { determined. }\end{array}$ & {$[28]$} \\
\hline $\begin{array}{l}\text { Liquid } \\
\text { chromatography- } \\
\text { tandem mass } \\
\text { spectrometry }\end{array}$ & & $\begin{array}{l}\text { Surface dust samples from both the homes of smokers } \\
\text { and non-smokers for nicotine derived carcinogen, 4- } \\
\text { (methylnitrosamino)-1-(3-pyridyl)-1-butanone (NNK). } \\
\text { Non-smokers' properties; }<30 \mathrm{pg} / 100 \mathrm{~cm}^{2}-435 \mathrm{pg} / 100 \\
\mathrm{~cm}^{2} ; \text { smokers'; } 37 \mathrm{pg} / 100 \mathrm{~cm}^{2}-3500 \mathrm{pg} / 100 \mathrm{~cm}^{2} \text {. }\end{array}$ & [29] \\
\hline $\begin{array}{l}\text { Liquid } \\
\text { chromatography- } \\
\text { tandem mass } \\
\text { spectrometry }\end{array}$ & Laboratory study. & $\begin{array}{l}\text { Cotton terry cloth and polyester fleece were exposed to } \\
\text { smoke in controlled laboratory conditions and aged } \\
\text { before extraction. Nicotine, myosmine, 2,3-bipyridine, } \\
\text { cotinine, N-formylnornicotine, nicotelline (3,2':4',3"- } \\
\text { terpyridine) NNN, NNK, NNA determined. Aqueous and } \\
\text { solvent (methanol/HCl) efficiency compared. }\end{array}$ & {$[30]$} \\
\hline Hydrophilic interaction & Surface nicotine non-smoker living rooms greater or equal to & Urine cotinine, finger and air nicotine measurements & [31] \\
\hline
\end{tabular}




\begin{tabular}{|c|c|c|c|}
\hline $\begin{array}{l}\text { liquid } \\
\text { chromatography- } \\
\text { tandem mass } \\
\text { spectrometry }\end{array}$ & $\begin{array}{l}\text { 5.0, } 16 \% \text {; smoker homes } 86 \% \text {; surface nicotine non-smoker } \\
\text { bedrooms greater or equal to 5.0, none detected; smoker } \\
\text { homes } 75 \% \text {. Dust nicotine non-smoker living rooms greater or } \\
\text { equal to 5.0, } 28 \% \text {; smoker homes } 90 \% \text {; dust nicotine non- } \\
\text { smoker bedrooms greater or equal to 5.0, none detected; } \\
\text { smoker homes } 84 \% \text {; dust nicotine non-smoker living rooms } \\
\text { greater or equal to 5.0, } 31 \% \text {; smoker homes, } 91 \% \text {. }\end{array}$ & made as well. & \\
\hline $\begin{array}{l}\text { Gas chromatography } \\
\text { with nitrogen selective } \\
\text { detection }\end{array}$ & $\begin{array}{l}\text { Experimental investigation using model materials (window, } \\
\text { walls, floor, wood, and metal). Three brands of e-cigarettes } \\
\text { were refilled with varying nicotine concentrations. One } \\
\text { hundred puffs were released from each product directly into } \\
\text { an exposure chamber. Surface wipe samples were taken from } \\
5 \text { indoor } 100 \mathrm{~cm}^{2} \text { surfaces and extracted with } 5 \mathrm{~mL} \text { of } \\
\text { methanol. }\end{array}$ & $\begin{array}{l}\text { Three of the four experiments showed significant } \\
\text { increases in the amount of nicotine on all five surfaces. } \\
\text { The floor and glass windows had the greatest increases in } \\
\text { nicotine, on average by a factor of } 47 \text { and } 6 \text {, respectively. }\end{array}$ & [32] \\
\hline $\begin{array}{l}\text { Gas chromatography } \\
\text { with nitrogen selective } \\
\text { detection and liquid } \\
\text { chromatography- } \\
\text { electrospray } \\
\text { ionization-tandem } \\
\text { mass spectrometry }\end{array}$ & No evidence for third-hand smoke exposure in this study. & $\begin{array}{l}\text { Children's urine examined for nicotine, cotinine and 4- } \\
\text { (methylnitrosamino)-1-(3-pyridyl)-1-butanol (NNAL). }\end{array}$ & [33] \\
\hline $\begin{array}{l}\text { Gas } \\
\text { chromatography/mass } \\
\text { spectrometry }\end{array}$ & $\begin{array}{l}\text { Furniture } 11-73 \text {; household dust } 0.89-4.43 \text {; vehicle } \\
\text { dashboard } 5.0-8.6 \text {; vehicle dust } 11.6-19.5 \text {. }\end{array}$ & Air nicotine and finger wipes also investigated. & [34] \\
\hline $\begin{array}{l}\text { Comprehensive gas } \\
\text { chromatography } \\
\text { nitrogen } \\
\text { chemiluminiscence } \\
\text { detection }\end{array}$ & $\begin{array}{l}\text { Smokers' house dust } 4.33-342 \text {. Non-smokers' house dust } \\
0.62-5.3 \text {. }\end{array}$ & Main tobacco specific $N$-nitrosamines also determined. & [8] \\
\hline $\begin{array}{l}\text { Gas chromatography- } \\
\text { mass spectrometry }\end{array}$ & $\begin{array}{l}\text { Levels ranging from } 0.184-0.256 \text { for households with one or } \\
\text { more non-smoking members; } 0.415-1.634 \text { households with } \\
\text { smokers. }\end{array}$ & $\begin{array}{l}\text { House dust was collected by high-volume surface } \\
\text { samplers and from household vacuum cleaners and } \\
\text { analysed for nicotine. }\end{array}$ & {$[35]$} \\
\hline
\end{tabular}




\begin{tabular}{|l|l|l|l|}
\hline $\begin{array}{l}\text { Gas chromatography- } \\
\text { mass spectrometry }\end{array}$ & $<0.020-7.776$ & $\begin{array}{l}\text { Household carpet dust. Polychlorinated biphenyls and } \\
\text { polyaromatic hydrogens also measured. }\end{array}$ & [36] \\
\hline $\begin{array}{l}\text { Gas chromatograph } \\
\text { ion trap - tandem } \\
\text { mass spectrometry }\end{array}$ & $\begin{array}{l}\text { Experimental investigation using model materials (cotton, } \\
\text { paper, and gypsum wallboard) exposed to ten smouldering } \\
\text { cigarettes in a } 24 \mathrm{~m}^{3} \text { room size chamber in the presence and } \\
\text { absence of ozone. }\end{array}$ & $\begin{array}{l}\text { Along with nicotine, ozone oxidation products cotinine, } \\
\text { myosmine and N-methyl formamide and nicotine-1-oxide } \\
\text { detected. }\end{array}$ & $\begin{array}{l}\text { [37] } \\
\text { HILIC UV detection }\end{array}$ \\
$<0.01-309$ & $\begin{array}{l}\text { Contamination of outside doors of communal entrances } \\
\text { by tobacco smoke. }\end{array}$ & $\begin{array}{l}\text { This } \\
\text { study }\end{array}$ \\
\hline
\end{tabular}

Table 1. Determination of third-hand smoke. 


\section{Experimental}

\section{Chemical and Reagents}

Nicotine was obtained from Sigma-Aldrich. The surface-wipes were fabricated by cutting $10 \mathrm{~cm}^{2}$ squares from a roll of tissue (one ply, Jangro White Centrefeed, Pattersons, Bristol, UK). Deionised water was obtained from a Purite RO200-Stillplus HP System, (Purite Oxon, UK). Acetonitrile was obtained from Fisher (Loughborough, UK).

\section{Instrumentation}

HILIC separation was performed using a system consisting of an IsoChrom pump (Spectra Physics), with a $150 \mathrm{~mm} \times 4.6 \mathrm{~mm}, 5 \mu \mathrm{m}$ Zorbax Carbohydrate Analysis column connected to a 7125 valve manual injector fitted with a $20 \mu \mathrm{L}$ sample loop (Rheodyne, Cotati, CA). Sample extracts were analysed using a mobile phase consisting of $90 \%$ acetonitrile (Fischer, far UV, HPLC grade), $10 \%$ water, at a flow rate of $1.0 \mathrm{~mL} / \mathrm{min}$ with UV detection at $259 \mathrm{~nm}$. Chromatograms were recorded using a Siemens Kompensograph X-T C1012 chart recorder. Sample extracts and standards were introduced using full loop injection. Quantification was achieved by manual integration using external calibration.

\section{Dust Wipe Sampling}

The glass fronting of doors and windows facing onto entranceways were chosen for investigation. Dust wipe samples were obtained by wiping from the upper left corner of the sample area; in " $\mathrm{S}$ " shape manner, wiping from side-to-side whilst moving down the sample area. The area sampled was measured in order that a comparison of concentration values $\left(\mu \mathrm{g} / \mathrm{m}^{2}\right)$ between different surfaces could be made. The exposed wipe was then folded in half, exposed side to exposed side and another "S" shape was made in the opposite direction wiping up and down instead of side-toside. The folded wipe was placed in an acetonitrile washed glass vial, which was also used as the extraction vessel and sealed. A new pair of gloves was also used for each sample. A procedural blank was obtained by taking a tissue on site but without sampling the surface.

\section{Sample Extraction and Analysis}


Five $\mathrm{mL}$ of acetonitrile was added to the glass vessel containing the dust wipe sample. This was then sealed and the dust wipe extracted by sonication for 15 minutes at room temperature. A $20 \mu \mathrm{L}$ aliquot of the resulting solution was then examined using the optimised HILIC conditions.

\section{Results and Discussion}

\section{Effect of Acetonitrile/Water Concentration on Chromatographic Performance}

The variation of chromatographic capacity factor $\left(k^{\prime}\right)$ of nicotine with the percentage of water in the mobile phase is shown in Figure 1. The optimum percentage of water was found to be $10 \%(\mathrm{v} / \mathrm{v})$, as this gave a retention time of only 5.5 minutes $\left(k^{\prime}=3.2\right)$ without compromising the chromatographic performance. Therefore, a mobile phase of $90 \%$ acetonitrile, $10 \%$ water was used in further studies.

\section{Calibration Curve, Limit of Detection, and Precision}

Standard solutions containing nicotine in the concentration range 0.05 to $24 \mu \mathrm{g} / \mathrm{mL}(1.0 \mathrm{ng}-480 \mathrm{ng}$ on column) were prepared in acetonitrile and determined by the optimized HILIC procedure. The calibration plot was found to be linear over the range investigated, with an $R^{2}$ value of 0.998 . The coefficient of variation was determined by performing six replicate measurements of a $1.50 \mu \mathrm{g} / \mathrm{mL}$ (30.0 ng on column) nicotine standard and was calculated to be $1.7 \%$. The limit of detection was calculated by making replicate measurements at the retention time of nicotine, 5.5 minutes $(n=5)$ for a blank solution. The detection limit based on three times the mean of these measurements gave a value of $1.0 \mathrm{ng}$ of nicotine on column.

\section{Studies of Possible Interferences}

A wide range of compounds are known to be present in cigarette smoke $[38,39]$ and potentially present in third-hand smoke [4] which could interfere with the determination of nicotine. Present as well, are residues from cleaning products and human contact. In the present study we have investigated acetone, toluene, phenol, naphthalene, musk ketone and palmitic acid all at $20 \mu \mathrm{g} / \mathrm{mL}$ as possible interferences. All the compounds investigated were found to elute as part of the unretained fraction and consequently did not interfere. 


\section{Extraction and Recovery of Nicotine from Dust Wipes \\ Optimisation of Extraction Procedure}

To assess the performance of the developed method, five replicate determinations of nicotine in spiked and unspiked dust wipe samples were undertaken. Five separate dust wipes were spiked with $5.10 \mu \mathrm{g}$ of nicotine and extracted with $5 \mathrm{~mL}$ of acetonitrile with aid of sonication for 15 minutes as described above in the Sample Extraction and Analysis section. A $20 \mu \mathrm{L}$ aliquot of the resulting solution was then introduced to the HPLC and quantification was achieved by external calibration. Table 2 shows the summaries the recovery and precision data obtained. A mean recovery of $96.2 \%$ with an associated coefficient of variation of $1.14 \%$ was obtained. As can be seen from this data, the developed method holds promise for the determination of such levels of nicotine.

\begin{tabular}{|c|c|c|c|}
\hline Sample & Nicotine added, $\mu \mathrm{g}$ & Nicotine found, $\mu \mathrm{g}$ & \% Recovery \\
\hline 1 & 5.10 & 4.84 & 94.9 \\
\hline 2 & 5.10 & 4.95 & 97.1 \\
\hline 3 & 5.10 & 4.90 & 96.1 \\
\hline 4 & 5.10 & 4.88 & 95.7 \\
\hline 5 & 5.10 & 4.96 & 97.3 \\
\hline
\end{tabular}

Mean recovery $=96.2 \%$, coefficient of variation $=1.14$

Table 2. Recovery and precision data for nicotine obtained for dust wipe samples.

Several reports have shown that poor recoveries can result due to the volatile nature of nicotine $[21,40]$. This can have dramatic effects in common extraction and concentration steps such as if the sample extract is subject to a nitrogen blow down step. To overcome this problem nicotine is commonly converted to its salt by the addition of acid to the sample extract. To investigate this effect, six separate $5 \mathrm{~mL}$ aliquots of acetonitrile were fortified with a $1.0 \mu \mathrm{g}$ of nicotine. Three of these were blown down to dryness under nitrogen at room temperature. The remaining three were first acidified with $10 \mu \mathrm{L}$ of concentrated $\mathrm{HCl}$ and then blown down to dryness with nitrogen. The 
resulting extracts were then reconstituted in $1.0 \mathrm{~mL}$ of mobile phase and examined by the optimised liquid chromatographic conditions. A mean recovery of $12.1 \%$ and $98.2 \%$ was obtained for the nonacidified and the acidified samples respectively. Consequently, in further studies all samples requiring nitrogen blown down were first acidified.

\section{Extraction and Analysis of Real Samples}

Dust wipe samples were collected from the glass panels of external entrance doors and extracted with $5 \mathrm{~mL}$ of acetonitrile by sonication as described above. All sample sites were found to be contaminated with nicotine levels that could be directly determine without the need for concentration step and hence did not require blowing down under nitrogen. Table 3 details the nicotine levels obtained for these samples.

\begin{tabular}{|l|c|}
\hline \multicolumn{1}{|c|}{ Sample } & Nicotine, $\mu \mathrm{g} / \mathrm{m}^{2}$ \\
\hline Entrance 1 & 5.09 \\
\hline Entrance 2 & 36.2 \\
\hline Entrance 3 & 244 \\
\hline Entrance 4 & 8.10 \\
\hline Smoking shelter & 309 \\
\hline
\end{tabular}

Table 3. Nicotine levels obtained for dust wipe samples.

\section{Conclusions}

This is the first report to our knowledge of levels of THS nicotine in outdoor communal areas, and is also the first report on the determination of nicotine in dust wipe samples by HILIC with UV detection. This has been shown to be a potentially simpler and economic alternative to commonly employed techniques such as liquid and gas chromatography/mass spectroscopy. 
A number of the samples investigated had notable concentrations of nicotine which are notably higher than that reported indoor household dust samples [8]. Results indicate that there is a potential issue with exposure to THS and further investigations are required.

Extractions of nicotine can be hampered by the volatile nature of nicotine, leading to poor recoveries resulting from losses during extraction and concentration steps, such as nitrogen blow down $[21,41]$. For the levels detected in this study a further concentration step was found unnecessary. The developed method avoids the need for such a concentration step and hence avoids such issues.

The introduction of the electronic cigarette has added further issues which have yet to be fully assessed $[32,42,43]$ and further investigations into their effects on THS needs to be addressed. In future studies we will also investigate the possible application of the assay for the determination of other pollutants and drugs [44,45]. HILIC has been shown to be fully compatible with electrochemical detection [25] and to be a sensitive method for the determination of nicotine [21] we will also investigate this as a possible alternative detection system. 


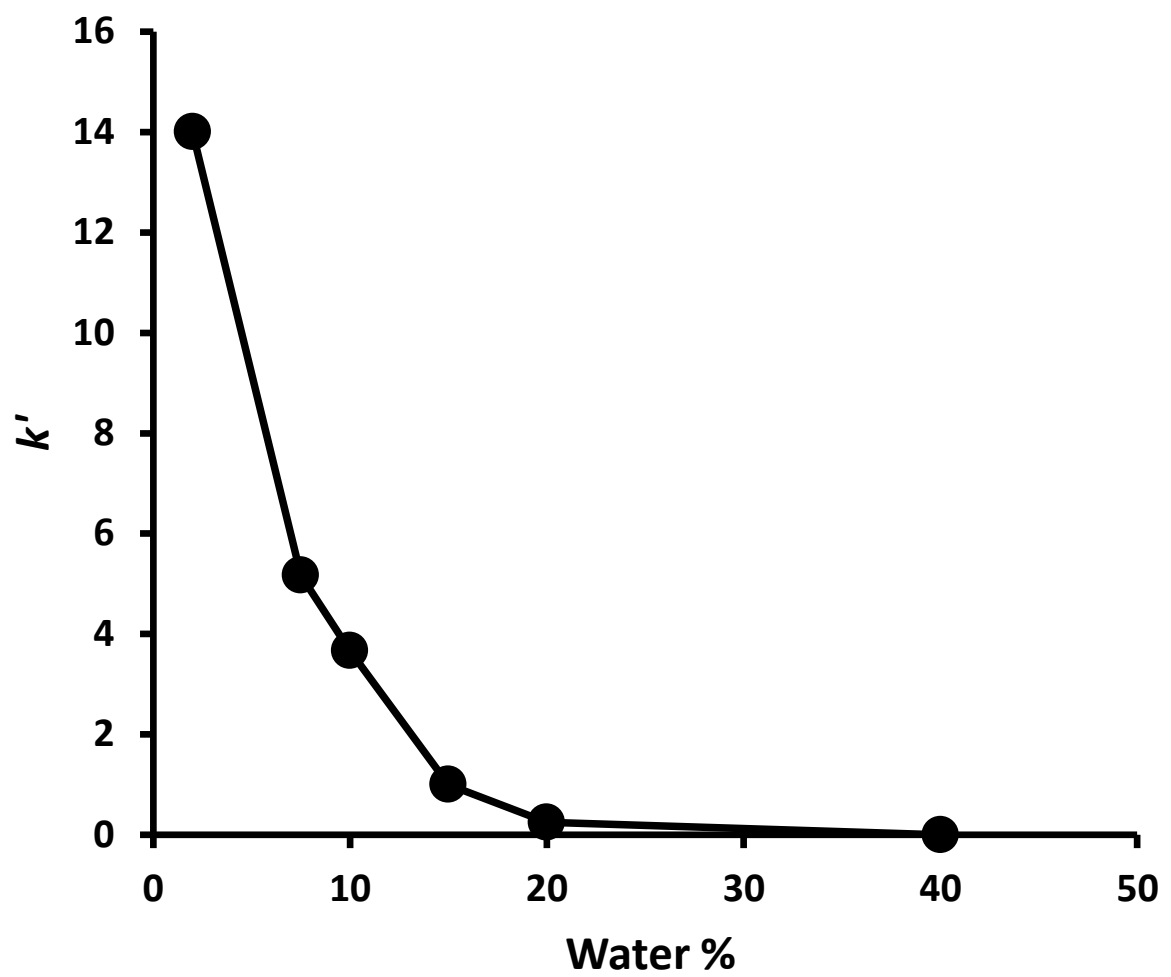

Figure 1. Variation of capacity factor $\left(k^{\prime}\right)$ with percentage of water in mobile phase. 

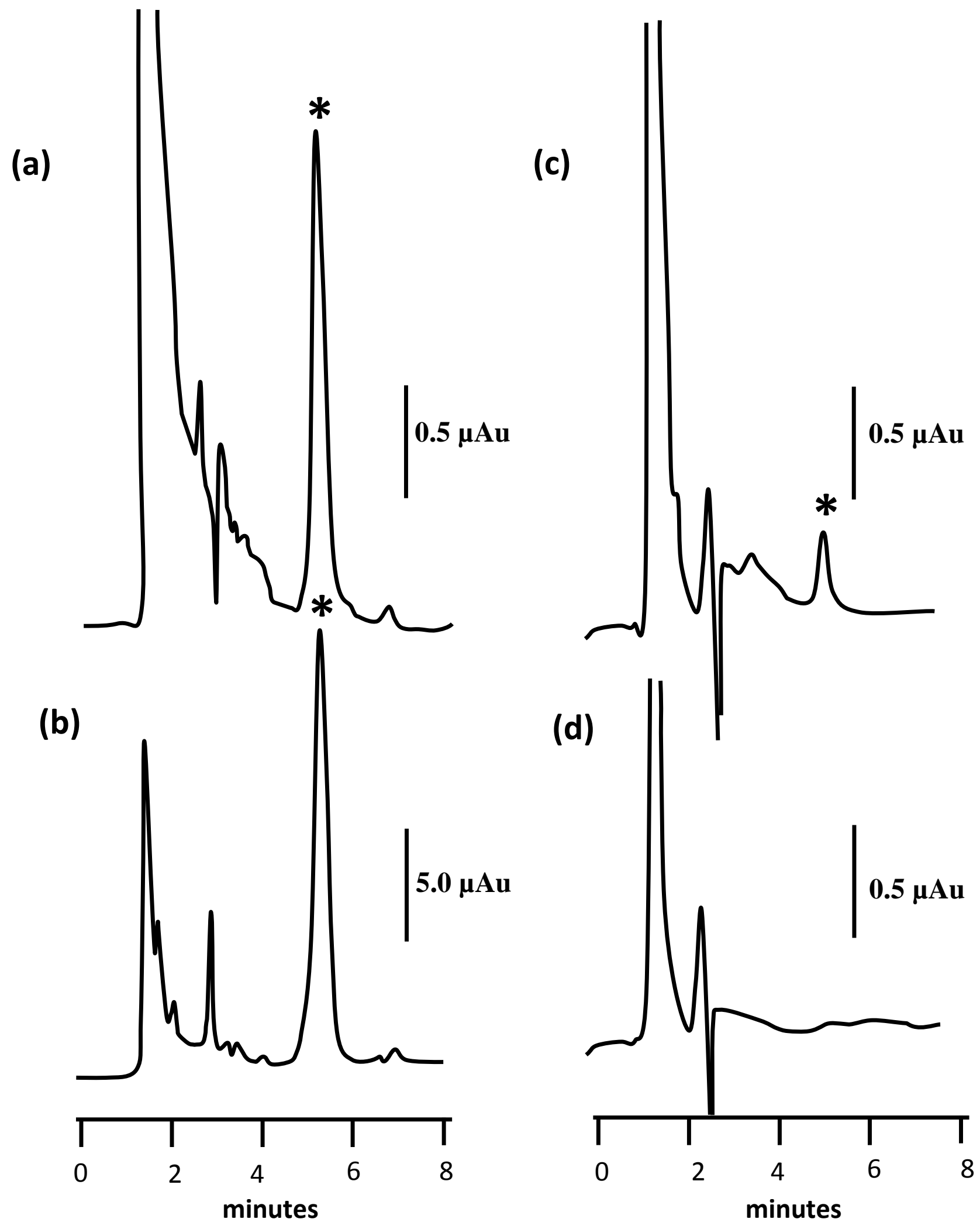

Figure 2. Representative chromatograms obtained for THS dust wipe samples for (a) Entrance 2; (b) Entrance 1; (c) Entrance 3 and (d) procedural blank. ${ }^{*}=$ nicotine 


\section{References}

[1] K. Bell, Science, Policy and the Rise of 'Thirdhand Smoke' As a Public Health Issue, Health Risk Soc. 2014, 16, 154.

[2] C. Ballantyne, What is third-hand smoke? Is it hazardous? Researchers warn cigarette dangers may be even more far-reaching Scientific American, Jan 6, 2009. Available: http://www.scientificamerican.com/article/what-is-third-hand-smoke/ [Accessed 17/7/14]

[3] A. Burton, Does the Smoke Ever Really Clear? Thirdhand Smoke Exposure Raises New Concerns, Environ. Health Perspect. 2011, 119, A70.

[4] G.E. Matt, P.J.E. Quintana, H. Destaillats, L.A. Gundel, M. Sleiman, B.C. Singer, P. Jacob III, N. Benowitz, J.P. Winickoff, V. Rehan, P. Talbot, S. Schick, J. Samet, Y. Wang, B. Hang, M. Martins-Green, J.F. Pankow, M.F. Hovell, Thirdhand Tobacco Smoke: Emerging Evidence and Arguments for a Multidisciplinary Research Agenda, Environ. Health Perspect. 2011, 119, 1218.

[5] L. Petrick, H. Destaillats, I. Zouev, S. Sabach, Y. Dubowski, Sorption, desorption, and surface oxidative fate of nicotine, Phys. Chem. Chem. Phys. 2010, 12, 10356.

[6] M. Martins-Green, N. Adhami, M. Frankos, M. Valdez, B. Goodwin, J. Lyubovitsky, S. Dhall, M. Garcia, I. Egiebor, B. Martinez, H.W. Green, C. Havel, L. Yu, S. Liles, G. Matt, H. Destaillats, M. Sleiman, L.A. Gundel, N. Benowitz, P. Jacob III, M. Hovell, J.P. Winickoff, M. CurrasCollazo, Cigarette Smoke Toxins Deposited on Surfaces: Implications for Human Health, PLoS ONE, 2014, 9, e86391.

[7] M. Sleiman, L.A. Gundel, J.F. Pankow, P. Jacob, B.C. Singer, H. Destaillats, Formation of carcinogens indoors by surface-mediated reactions of nicotine with nitrous acid, leading to potential thirdhand smoke hazards. Proc. Natl. Acad. Sci. U.S.A. 2010, 107, 6576.

[8] V.K. Rehan, R. Sakurai, J.S. Torday, Thirdhand smoke: a new dimension to the effects of cigarette smoke on the developing lung. Am. J. Physiol. Lung Cell Mol. Physiol. 2011, 301, L1.

[9] N. Ramírez, M.Z. Özel, A.C. Lewis, R.M. Marcé, F. Borrull, J.F. Hamilton, Exposure to nitrosamines in thirdhand tobacco smoke increases cancer risk in non-smokers, Environ. Int. 2014, 71, 139.

[10] P.J.E. Quintana, G.E. Matt, D. Chatfield, J.M. Zakarian, A.L. Fortmann, E. Hoh, Wipe Sampling for Nicotine as a Marker of Thirdhand Tobacco Smoke Contamination on Surfaces in Homes, Cars, and Hotels, Nicotine Tob. Res. 2013, 15, 1555.

[11] B. Hang, A.H. Sarker, C. Havel, S. Saha, T.K. Hazra, S. Schick, P. Jacob III, V.K. Rehan, A. Chenna, D. Sharan, M. Sleiman, H. Destaillats, L.A. Gundel, Thirdhand smoke causes DNA damage in human cells, Mutagenesis 2013, pp. 1-11.

[12] T.A. Merritt, J. Mazela, A. Adamczak, T. Merritt, The impact of second-hand tobacco smoke exposure on pregnancy outcomes, infant health, and the threat of third-hand smoke exposure to our environment and to our children, Przegl. Lek. 2012, 69, 717.

[13] C. Protano, R. Andreoli, P. Manini, M. Vitali, How home-smoking habits affect children: a cross-sectional study using urinary cotinine measurement in Italy, Int. J. Public Health, 2012, 57,885 .

[14] G. Ferrante, M. Simoni, F. Cibella, F. Ferrara, G. Liotta, V. Malizia, G. Corsello, G. Viegi, S. La Grutta, Third-Hand Smoke Exposure and Health Hazards in Children. Monaldi Arch. Chest Dis. 2013, 79, 38.

[15] G.N. Lucas, Third-hand smoke and children, Sri Lanka Journal of Child Health, 2011, 40, 87.

[16] IARC (International Agency for Research on Cancer). IARC monographs on the evaluation of the carcinogenic risks to humans - tobacco smoke and involuntary smoking, vol. 83. Available: http://monographs.iarc.fr/ENG/Monographs/vol83/volume83.pdf, 2004. [Accessed: 17/7/14]. 
[17] P. Dhar, Measuring tobacco smoke exposure: quantifying nicotine/cotinine concentration in biological samples by colorimetry, chromatography and immunoassay methods, J. Pharm. Biomed. Anal. 2004, 35, 155-168.

[18] G.A. Eiceman, S. Sowa, S. Lin, S.E. Bell, Ion mobility spectrometry for continuous on-site monitoring of nicotine vapors in air during the manufacture of transdermal systems, $J$. Hazard. Mater. 1995, 43, 13-30.

[19] A. Hannisdal, O. Mikkelsen, K.H. Schroder, Analysis of nicotine in antismoking pharmaceutical products by differential pulse polarography and voltammetry, Collect. Czech. Chem. Commun. 2007, 72, 1207-1213

[20] R. Dawson, Jr, S.M. Messina, C. Stokes, S. Salyani, N. Alcalay, N.C. de Fiebre, C.M. de Fiebre, Solid-Phase Extraction and HPLC Assay of Nicotine and Cotinine In Plasma and Brain, Toxicol. Mech. Meth. 2002, 12, 45-58.

[21] G.N. Mahoney, W. Al-Delaimy, Measurement of nicotine in hair by reversed-phase highperformance liquid chromatography with electrochemical detection. J. Chromatogr. B Biomed. Sci. Appl. 2001, 753, 179-187.

[22] D.V. McCalley, Liquid chromatographic separations of basic compounds, Adv. Chromatogr. 46 (2008) 305-350.

[23] D.V. McCalley, The challenges of the analysis of basic compounds by high performance liquid chromatography: Some possible approaches for improved separations, J. Chromatogr. A 2010, 1217, 858.

[24] B. Buszewski, S. Noga, Hydrophilic interaction liquid chromatography (HILIC) -a powerful separation technique, Anal. Bioanal. Chem. 2012, 402, 231-247.

[25] A. Kumar, J.P. Hart, D.V. McCalley, Determination of catecholamines in urine using hydrophilic interaction chromatography with electrochemical detection, J. Chromatogr. A, 2011, 1218, 3854-3861.

[26] G.E. Matt, P.J.E. Quintana, A.L. Fortmann, J.M. Zakarian, V.E. Galaviz, D.A. Chatfield, E. Hoh, M.F. Hovell, C. Winston, Thirdhand smoke and exposure in California hotels: non-smoking rooms fail to protect non-smoking hotel guests from tobacco smoke exposure, Tob. Control 2013, 0:1-9.

[27] N.E. Hood, A.K. Ferketich, E.G. Klein, P. Pirie, M.E. Wewers, Associations between selfreported in-home smoking behaviours and surface nicotine concentrations in multiunit subsidised housing, Tob. Control 2014, 23, 27-32.

[28] N.O.F. Kassem, R.M. Daffa, S. Liles, S.R. Jackson, N.O. Kassem, M.A. Younis, S. Mehta, M. Chen, P. Jacob III, S.G. Carmella, D.A. Chatfield, N.L. Benowitz, G.E. Matt, S.S. Hecht, M.F. Hovell, Children's Exposure to Secondhand and Thirdhand Smoke Carcinogens and Toxicants in Homes of Hookah Smokers, Nicotine Tob. Res. 2014, 16, 961.

[29] J.L. Thomas, S.S. Hecht, X. Luo, X. Ming, J.S. Ahluwalia, S.G. Carmella, Thirdhand Tobacco Smoke: A Tobacco-Specific Lung Carcinogen on Surfaces in Smokers' Homes, Nicotine Tob. Res. 2014, 16, 26-32.

[30] V. Bahl, P. Jacob III, C. Havel, S.F. Schick, P. Talbot Thirdhand Cigarette Smoke: Factors Affecting Exposure and Remediation. PLOS ONE 2014, 9, e108258. doi:10.1371/journal.pone. 0108258

[31] G.E. Matt, P.J.E. Quintana, J.M. Zakarian, A.L. Fortmann, D.A. Chatfield, E. Hoh, A.M. Uribe, M.F. Hovell, When smokers move out and non-smokers move in: residential thirdhand smoke pollution and exposure, Tob. Control, 2010, 20, e1.

[32] M.L. Goniewicz, Lily Lee, Electronic Cigarettes Are a Source of Thirdhand, Exposure to Nicotine, Nicotine Tob. Res. 2015, 17, 256-258.

[33] J.L. Thomas, H. Guo, S.G. Carmella, S. Balbo, S. Han, A. Davis, A. Yoder, S.E. Murphy, L.C. Ana, J.S. Ahluwalia, S.S. Hecht, Metabolites of a Tobacco-Specific Lung Carcinogen in Children 
Exposed to Secondhand or Thirdhand Tobacco Smoke in Their Homes, Cancer Epidemiol. Biomarkers Prev. 2011, 20, 1213.

[34] G.E. Matt, P.J.E. Quintana, M.F. Hovell, J.T. Bernert, S. Song, N. Novianti, T. Juarez, J. Floro, C. Gehrman, M. Garcia, S. Larson, Households contaminated by environmental tobacco smoke: Sources of infant exposures, Tob. Control 2004, 13, 29.

[35] T. Whitehead, C. Metayer, M.H. Ward, M.G. Nishioka, R. Gunier, J.S. Colt, P. Reynolds, S. Selvin, P. Buffler, S.M. Rappaport, Is house-dust nicotine a good surrogate for household smoking? Am. J. Epidemiol. 2009, 169, 1113.

[36] T.P. Whitehead, J.R. Nuckols, M.H. Ward, S.M. Rappaport, Carpet-dust chemicals as measures of exposure: Implications of variability, Emerg. Themes Epidemiol. 2012, 9:2

[37] L.M. Petrick, M. Sleiman, Y. Dubowski, L.A. Gundel, H. Destaillats, Tobacco smoke aging in the presence of ozone: a room-sized chamber study, Atmos. Environ. 2011, 45, 4959.

[38] G. Barrefors, G. Petersson, Assessment of ambient volatile hydrocarbons from tobacco smoke and from vehicle emissions, J. Chromatogr. 1993, 23, 71.

[39] M.E. Counts, M.J. Morton, S.W. Laffoon, R.H. Cox, P.J. Lipowicz, Smoke composition and predicting relationships for international commercial cigarettes smoked with three machinesmoking conditions. Regul. Toxicol. Pharmacol. 2005, 41, 185.

[40] H.-S. Shin, J.-G. Kim, Y.-J. Shin, S.H. Jee, Sensitive and simple method for the determination of nicotine and cotinine in human urine, plasma and saliva by gas chromatography-mass spectrometry, J. Chromatogr. B. 2002, 769, 177-183.

[41] H. James, Y. Tizabi, R. Taylor, Rapid method for the simultaneous measurement of nicotine and cotinine in urine and serum by gas chromatography-mass spectrometry, J. Chromatogr. B. Biomed. Sci. Appl. 1998, 708, 87-93.

[42] P. Callahan-Lyon, Electronic cigarettes: human health effects, Tob. Control 2014, 23, ii36.

[43] Kuschner W.G., Reddy S., Mehrotra N., Paintal H.S. Electronic cigarettes and thirdhand tobacco smoke: two emerging health care challenges for the primary care provider, Int. J. Gen. Med. 2011, 4, 115.

[44] B.A. Goldberger, D.A. Martin, N.A. Graham, M.S. Gold, Second- and Third-Hand Opium Exposure in the Women and Children of Afghanistan, Biol. Psychiatry, 2011, 69, $245 \mathrm{~S}$. Supplement: S Meeting Abstract: 818.

[45] M.S. Gold, N.A. Graham, B.A. Goldberger, Second-Hand and Third-Hand Drug Exposures in the Operating Room: A Factor in Anesthesiologists' Dependency on Fentanyl, J. Addict. Dis. 2010, 29, 280. 